\title{
Environmental Wisdom in Management of Tourism Village Penglipuran in Bangli Regency
}

\author{
A.A. Rai Sita Laksmi ${ }^{1}$, Anak Agung Gede Oka Wisnumurti ${ }^{2}$, I Made Mardika ${ }^{3}$ \\ \{sitalaksmi08@gmail.com $\left.{ }^{1}\right\}$ \\ Master of Public Administration Postgraduate Program Warmadewa University ${ }^{123}$
}

\begin{abstract}
Bali's natural environment is one of the tourist attractions besides cultural heritage. In the development of Bali tourism, it is not uncommon for physical development to contradict the natural environment so that it tends to over exploit nature without considering Bali's natural characteristics. In addition, it is not uncommon for the perpetrators of the development of Anmesia to be the wisdom of Balinese civilization that has been tested in maintaining environmental balance. Therefore, research on local cultural values about environmental sustainability is important. This study seeks to examine environmental wisdom in managing the attraction of Penglipuran Tourism Village, in Kubu Village, Bangli Regency. The aim is to find out the form and meaning of environmental wisdom in managing tourism villages. There are two theories used in this study, namely the theory of ecocentrism and the theory of discourse on knowledge of power. The method of data collection is done by observation, in-depth interviews, and document studies, and data analysis is descriptive qualitative. The results of the study show a form of environmental wisdom in managing the attraction of Penglipuran tourism village in the form of wisdom in settlement management, forest management, and tourism village management. The meaning of environmental wisdom in the management of Penglipuran tourism village includes the meaning of nature conservation, sociocultural meaning, and economic meaning. This study recommends that managing alternative tourism in Bali should implement eco-tourism-based tourism (ecotourism).
\end{abstract}

Keywords: Environmental Wisdom, Management of Tourist Attractions, Tourist Villages.

\section{Introduction}

Bali's natural environment is one of the tourist attractions besides cultural heritage. According to Ardika, tourist objects and attractions containing cultural and natural heritage amounted to 46 out of 185 (46\%) of objects and attractions in Bali [1] . However, in the development of Bali tourism it is not uncommon for physical development to contradict the natural environment so that it tends to over exploit nature without considering Bali's natural characteristics. In addition, it is not uncommon for the perpetrators of the development of Anmesia to be the wisdom of Balinese civilization that has been tested in maintaining environmental balance [2].

The wisdom of the Balinese people in preserving the environment has been known as the Ancient Bali. Ancient Balinese people always consider and give special space to the 
balance of the environment in physical development. This can be observed from the establishment of cliff temples along the Pakerisan river, which were intended to keep the area clean and avoid exploitation. Likewise in the inscription, the Government of Ancient Bali has determined policies in forest management such as the prohibition of logging certain vegetation, determining land use, and liberating forest areas to be used as agricultural land. All of that is the wisdom of the ancient Balinese people who until now still tradition [2].

The tradition of environmental preservation seems to be carried out by the local community (Pakraman village). In the Awig-awig of Pakraman village it strictly regulates the provisions of environmental regulation such as yards, lawns, rice fields, buildings, trees and animals. These provisions contain local wisdom that reflects justice, balance and order to be able to maintain and maintain harmonious relations with the environment. Awig-awig also regulates the maintenance of the environment such as the prohibition of cutting down trees which, if observed, contain wisdom which means conservation [3].

In the development of tourism, the government also gives attention to the wisdom of Balinese culture related to the environment. Bali Provincial Regulation No. 2 of 2012 states that tourism development must be done by paying attention to local wisdom such as Balinese people's beliefs based on Tri Hita Karana and environmental preservation such as traditions, Balinese customs, environmental regulations.

The development of an ancient village into a tourist village has become very interesting, and is mainly concerned with the efforts of the community in protecting the environment. One of the ancient village villages that was developed into a tourist village is Penglipuran Village, Kubu Village, Bangli Regency. This village has a unique form of linear settlement patterns with terraced structures. As a kono village, it is believed that the people of Penglipuran Village have good rules, provisions and values relating to environmental preservation. Based on this, the research entitled "environmental wisdom in managing the attraction of Penglipuran Tourism Village" is very important to know the model of environmental preservation in the management of the tourist village of Penglipuran.

The purpose of this study was to determine the shape and meaning of environmental wisdom in managing the attraction of Penglipuran Tourism Village. The benefits of this research are theoretically useful for the development of science and technology and adding to the list of references of other researchers who want to explore environmental wisdom in managing tourism villages. Practically beneficial to the government as a guideline in determining policies in the management of tourism villages based on environmental wisdom. Like wise for the community it is useful as a foundation in the management of tourism villages based on environmental wisdom.

\section{Methodology}

This research was designed using qualitative methods [4], by collecting descriptive data in the form of written and oral words. In addition, observations were also made on people's behavior in an effort to preserve the environment. The research location is in Penglipuran Village, Kubu Subdistrict, Bangli Regency, which is a Bali Aga Village that is full of local cultural values as a foundation for environmental preservation. As a unique old village, Penglipuran Village has been developed into a tourist village. 
The type of data collected is qualitative data supported by quantitative data in the form of numbers, such as population and community income. The data sources used are primary and secondary data [5] with Instruments [6]. The main research is the researchers themselves supported by interview guidelines, and anecdotal records. Data collection is done by observation techniques, interviews, and study of documents Data analysis performed with qualitative analysis includes data reduction, data presentation, and conclusion [7]. Presentation of the results of data analysis is done by describing words in scientific language.

\section{Result and Discussion}

\subsection{Environmental Conditions of Penglipuran Tourism Village}

The environment of Penglipuran Tourism Village is a unity of space with all objects including humans and behavior that affect the overall management of tourist village activities. Viewed from the physical environment, Penglipuran Village includes the Kubu Village area, Bangli District, Bangli Regency, Bali Province. The village is located on the northern border of the Kayang Customary Village, east of the Adat Village of Kubu, south of the Adat Village of Cempaga, and west of the Adat Cekeng Village. The area of Penglipuran village is 112 ha, covering 50ha of agricultural land, 4ha of timber forest, 45ha of bamboo forest, 9ha of residential areas, and 4ha of holy sites.

From the biotic environment, plants that grow as agricultural produce of dry land or moor in the form of cassava, sweet potato, chili, spinach, and taro. Whereas plantation products are in the form of fruits such as oranges, mangosteen, bark, papaya, durian, banana, coconut and coffee. Besides that, in Penglipuran Village also has a forest area in the form of timber forest and bamboo forest which is located in the north and west of the village.

Judging from the socio-cultural aspects, Penglipuran Village has a population of 936 people (233 families) including 469 men and 467 women. The livelihood of the majority of the population is craftsmen. Penglipuran Village is a village village headed by the head of the environment. In terms of customs, the village of Penglipuran consists of one desa adat and one banjar adat led by bendesa adat as well as kelihan adat assisted by penyarikan. Besides the desa adat teacher, in Penglipuran Village there is also an prajuru hulu apad called Jero Kancan Roras consisting of twelve people namely Jero Bayan Mucuk, Jero Bayan Nyoman, Jero Bahu Mucuk, Jero Bahu Nyoman, Jero Singgukan Mucuk, Jero Singgukan Nyoman, Jero Cacar Mucuk, Jero Cacar Nyoman, Jero Balung Mucuk, Jero Balung Nyoman, Jero Pati Mucuk, Jero Pati Nyoman. The structure shows that the village of Pakraman Penglipuran is a village of Bali Aga which is collective in nature, where the kelihan and kancan roras of the village are leaders or elders. Krama Penglipuran Customary Village consists of a number of krama pengarep with 76 families including 45 people in warga pangarep who own a tanah ayahan desa (AYDS) and 31 people do not own AYDS land. In Penglipuran Village there are also beberapa seka, as seka gong, baris, peratengan, pecalang, and seka teruna. As an ancient village, Penglipuran Village has unique cultural heritage such as village settlement spatial patterns and cultural values related to the environment. 


\subsection{Form of Environmental Wisdom in Tourism Village Management Penglipuran}

Environmental wisdom is a community idea that is wise and has good value for the environment. Environmental wisdom can not only be reflected in cultural heritage [8], it is also reflected in various forms of cultural values such as belief systems, myths, technological values, and customary rules [3]. The environmental wisdom in managing Penglipuran Tourism Village is a community idea about the environment that is implemented in the management of tourist villages as follows:

\subsubsection{Settlement Management Wisdom}

Settlements are parts of the environment outside protected areas in the form of urban and rural areas that function as neighborhoods or dwellings and places of activity that support livelihoods and livelihoods (Law No. 4 of 1992). The settlement of Penglipuran Village is a rural area that functions as a place of activity and residence for residents.

The settlement pattern of Penglipuran Village is linear in shape stretching from north to south and the middle part is the main road that divides settlements into two parts, namely the eastern part (kangin) and the western part (kauh). Such developments indicate an orientation at sunrise and sunset centered on the main road as an axis as well as open space for the community. The pattern of settlements in Penglipuran Village also shows the characteristics of the megalithic tradition that appears on the terraced structures, the higher the northward. The structure shows the orientation towards the mountain-sea, kaja-kelod, hulu-teben where the direction of kaja is the most sacred place and the place of residence of the gods. The settlement orientation of Penglipuran Village is in line with the dualism concept that has been known since the Prahindu period, namely the community's trust in two different but interrelated things such as kaja-kelod, kangin-kauh, gunung-laut, luanteben.

The settlement pattern of Penglipuran Village is also divided into three, namely the northern part is the temple, the most sacred part (main mandala) or the head part is the place of the gods (parhayangan), the middle part (madya mandala) as a housing and public facilities (pawongan); and the southern part of Nista Mandala) as downstream or foot is a grave of a dirty place (palemahan). The division shows the application of the Tri Mandala concept, namely the main, intermediate, and non-mandala; Tri Angga covers the head, body and legs, and Tri Hita Karana, parhyangan, pawongan, and palemahan. These values also indicate that Penglipuran Village has environmental wisdom in water channel management, where the upstream part as a sacred area is located higher than the residential part. With a sloping position like that, when the rainy season the water will flow smoothly and not inundate the settlement.

The concept of Tri Mandala, Tri Angga, and Tri Hita Karana also underlies the structure of the residence where each yard is divided into three, namely the sacred part (utama mandala) in the northeast is a holy place. The middle part (madya mandala) is a residence that consists of paon, bale sakanem, and loji. Nista mandala is located behind the yard called teba which is used as a place for gardening and raising livestock.

In the development of tourist villages, the settlement pattern of Penglipuran Village was developed in accordance with the interests of tourism while maintaining and preserving existing spatial patterns. The settlement pattern was developed into two zones, namely the conservation zone and the development zone. The conservation zone is a front residential area which is a traditional residential pattern that maintains uniformity. The development 
zone is in the back (tebe) which was developed to support tourism such as lodging and business premises. In the development of tourist villages, traditional values related to settlement patterns are still maintained in addition to modern values so that both develop in a balanced and side by side. The explanation above shows that the settlement pattern of Penglipuran Village is based on values to maintain the harmonization of relations between humans and God, humans and humans, and humans and the environment.

\subsubsection{Forest Management Wisdom}

Forest is an ecosystem unit in the form of expanse of land containing biological natural resources which are dominated by trees in the fellowship of their natural environment, one and the other cannot be separated. To maintain sustainability, it needs to be managed. Forest management includes the use of forests and the use of forest areas, forest protection, and nature conservation (Law No. 41 of 1999).

Forests in Penglipuran Tourism Village consist of timber forests and bamboo forests. Timber forest is located in the north of the village covering an area of 4ha, which is profit pura. Most of the trees planted are Majegau wood trees. Whereas bamboo forests are located behind timber forests in the north and west of the village covering an area of 45ha. The bamboo forest is partly owned by the Penglipuran Traditional Village and partly owned by local residents. The types of bamboo in Penglipuran Village are jajang aya bamboo, jajang aya, jajang bali, jajang panting, jajang taluh, jajang papah, jajang batu, tambang gading, tambang, petung buluh, buluh, tali suet, tali, gading, ampel.

In forest management, the Penglipuran community has a belief that to cut down wood or bamboo in the forest area must first carry out the ceremony of begging (God begging) which manifests as the ruler of the forest. Besides that, it must also be done by checking good days (adult ayu) which are set in the Balinese calendar. If the felling of a tree is done does not use a good day, it is believed that the forest will be damaged, dry up and die. The felling of trees done must also get the permission of the traditional village. This contains the value that tree felling is not carried out carelessly so that the forest remains sustainable.

The existence of timber forests and bamboo contains important values in people's lives. The wood produced is used to repair buildings in the temple. While bamboo is used to make roofs of angkul, houses, and traditional ceremonies. Besides the forest is also an ecological function to strengthen the cliffs on the north and west sides of the village, store water content, and fertilize the soil due to weathering. Forests also have conservation benefits which are as absorbers of water during rain and clean water providers in the dry season.

In the development of tourist villages, the Penglipuran Community developed the potential of the forest as a tourist attraction. The community makes a trail between the forests that tourists use to carry out road activities by tracing the forest by bicycle (tracking and cycling). Forest conservation and utilization efforts in Penglipuran Village received appreciation from the government. In 1995 Penglipuran Village received the Kalpataru award from the central government for environmental protection.

\subsubsection{Tourism Village Management Wisdom}

The management of Penglipuran Village as a tourism village was determined through the Decree of the Head of the Bangli Regional Level II Number 115 of 1993 concerning the Determination of Tourism Objects in Bangli Regency. Furthermore, based on the 
Decree of the Head of the Level II Bangli Number 116 in 1993 the Government appointed the Penglipuran Customary Village as an officer to collect tourist fees for every tourist and vehicle entering the Tourism Object. In addition, the government also requires Penglipuran Village to maintain cleanliness, beauty and sustainability of tourist attractions.

With the increase in the number of tourist visits, on May 1, 2012 the Penglipuran Customary Village formed the Penglipuran Tourism Village Management Institute which was under the adat village and was fully responsible to the traditional villages. The position of this institution is in line with the position of Seka in Penglipuran Village (Profile of Penglipuran Tourism Village, 2013: iv). The Management Institution has a vision to make village tourism community-based, cultured and environmentally sound. While the stated mission is to increase community participation in developing tourism; improve skills in tourism development; improve community welfare; preserve art and culture; and preserve the environment with the concept of Tri Hita Karana.

The management of village tourism carried out by managing institutions was apparently inseparable from the involvement of local communities such as the Penglipuran Traditional Village. The role of traditional villages in the management of tourist villages can be observed from the position of customary villages in the management institutions, namely as a supervisory board whose task is to provide direction to managers and provide input and solutions to the problems faced. Besides that, desa adat also has the authority to decide everything related to the management of tourist villages. That is, in managing tourism villages the local community is involved in the planning, implementation and evaluation.

In the management of Penglipuran tourism village, the local community also develops crafts and culinary specialties of Penglipuran Village in the form of loloh cemcem, loloh kunyir, kelepon of purple yams, and sweet potato chips. This shows the ability of local communities to develop their own environmental resources. This phenomenon shows that the Penglipuran community has developed local variations which emphasize the learning process among citizens from the planning process to evaluation. In addition, the local community also seeks to establish a network between Indigenous Villages, management institutions, and the government. That is, in managing tourism villages, local communities are involved formally and informally. Formally, traditional villages occupy the highest position in the structure of the management institution and informally the community contributes to developing local resources in accordance with their capabilities.

From the explanation above, it appears that environmental wisdom or rules regarding the environment implemented in settlement management, forest management, and management of tourist villages are ethically oriented that the universe is a unit that is interrelated and meaningful. This is in line with the environmental ethic view of ecocentrism which emphasizes the linkages of all organisms and anorganisms in the ecosystem. According to this view, planet earth is an integral plant, an entire organism that needs each other and supports one another. This view also emphasizes humans as an integral part of the environment, emphasizes the similarity of values of human and nonhuman life, and the importance of ecosystems and respect for nature [9].

\subsection{Meaning of Environmental Wisdom in Tourism Village Management}

The meaning of environmental wisdom in the management of tourist villages is interpreted through cultural values about the environment that have a purpose and meaning for the community in managing tourism villages. As mentioned by Barker [10], the meaning lies in the attitudes, beliefs, goals, truths, and reasons used by everyday people. 
The meaning shows that something has meaning and guides actions as an explanation and justification for these actions "after they occur". The meaning of environmental wisdom in managing the attraction of Penglipuran tourism village is as follows:

\subsubsection{The Meaning of Nature Conservation}

The preservation of the environment as mentioned in Law No. 32 of 2009 is an effort to maintain the continuity of the carrying capacity and capacity of the environment. Environmental management objectives include protecting the area from pollution and environmental damage, maintaining environmental functions, controlling the use of natural resources wisely, realizing sustainable development, and anticipating global environmental issues. The meaning of environmental wisdom in nature conservation lies in the beliefs, attitudes, and goals of the Penglipuran community in preserving nature in their daily lives. Community trust and attitudes mean and guide actions to create a sustainable natural environment.

Nature conservation efforts in Penglipuran Village have been carried out by the community, management institutions, and the government. Preservation by the community that the Penglipuran village community is very aware of the existing awig-awig. For forest conservation, traditional villages have awig-awig which states "tetanguran manut padruwen desa" means plants belonging to the village. If there are people who take forest products for personal gain without the knowledge of village officials, the person will be penalized. The community has also agreed that wood and bamboo as forest products can only be used by the community for yadnya interests.

In Penglipuran village there is also a tradition of the ceremony of tumpek pengatag, tumpek kandang, and tradisi ngusaba bantal. The tumpek pengatag ceremony is a ceremony of respect for God in its manifestation as the creator of plants. The tumpek pondok ceremony is a ceremony of respect for God in its manifestation as the creator of animals. The tradisi ngusaba bantal is the ceremony of honoring God for the crops they enjoy. The community also carries out various activities such as planting trees around the yard, cleaning the yard and telajakan, holding community work carried out according to the schedule set by prajuru adat.

Environmental preservation by village tourism management institutions is carried out every day. One part of the management institution that is responsible for environmental sustainability is the hygiene and gardening section. This section is in charge of cleaning certain places such as Bale Banjar, village landscaping, and around bamboo forests every day according to the set schedule.

Likewise, with the Bangli Regency Government, through the Department of Hygiene and Landscaping (DKP) every day they carry out their duties to clean the environment along the main road to Penglipuran Village until Tugu Pahlawan. In addition, visitors are also required to maintain cleanliness and environmental sustainability. For this reason, hygiene infrastructure has been provided such as trash bins placed in strategic places including in front of the Bale Banjar, in front of Pura, and in front of the residents' houses.

The involvement of all components in safeguarding the environment shows a shared responsibility for nature conservation. The efforts made by stakeholders give importance to the sustainability and maintenance of wood and bamboo forests, beautiful and beautiful residential environments to maintain Penglipuran Village remain unique and become a sustainable tourist attraction. This is in line with Government Regulation Number 2 of 2012 article 27 that everyone must help create a safe, orderly, clean, polite manner and 
maintain the environment of tourism destinations. The relationship between humans and nature is an inseparable entity that can be likened to "like a fetus in the womb" or " sekadi manik ring cacupu " (http://biohabbites.blogspot.com/). Humans are likened to manik (fetus) and nature as cacupu (womb). This view implies that human beings are surrounded by nature and that from nature they have the means to live. That is, that humans live freely in their attachment to nature that humans are free to take anything from nature but they are obliged to preserve it.

\subsubsection{Socio-cultural meaning}

Environmental wisdom in attractiveness management of tourist villages is inseparable from social and cultural life. In social life, it appears from inter-human relations arranged according to rules that synergy between community involvement in the management of tourist villages. In this case, the community plays an active role in the management of tourist villages both formally and informally. Formally the community as prajuru adat are directly involved as managers so that the social relations between traditional local communities in managing modern organizations run in a balanced manner. Nonformally, to support the development of community tourism villages get non-formal education in the form of coaching, counseling, and training in the form of village tourism management workshops, training of local guides and traders, practical English training provided by the government and the private sector.

In the context of culture, environmental wisdom has implications for maintaining cultural heritage in the form of traditional house buildings, historical places, arts, and customs. In an effort to support the preservation of cultural heritage, the management and desa adat do repairs to temples and traditional houses. For traditional house buildings, subsidies for repairing damaged buildings such as angkul-angkul, paon, and bale sakanem are Rp. 25,000,000 - Rp. 30,000,000.00, with funds from the management of tourist villages. Likewise, the case with historical places such as hero monuments is always maintained and repaired in the event of damage. Art and tradition continue to be explored and developed to support the progress of tourist villages.

Thus, the environmental wisdom in the management of tourist villages gives importance to the social life of the community especially in improving the harmonization of relations between humans and society. In addition, it also gives importance to the maintenance of local cultural heritage that remains oriented towards its original culture. This is in line with the goal of cultural tourism, which is to preserve Balinese culture inspired by Hindu values. Related to conservation, it is emphasized in Law Number 11 of 2010 that conservation is a dynamic effort to maintain cultural heritage and its value by protecting or preventing it from damage, developing by increasing the value of information, and utilizing it by utilizing it for the benefit of public welfare.

\subsubsection{Economic meaning}

Environmental wisdom with the involvement of desa adat Penglipuran in the structure of the Tourism Village Management Institution has implications for the acquisition of tourism village management revenues originating from entrance ticket fees. The ticket price for admission to Penglipuran Village for foreign tourists is IDR 30,000.00 for adults and IDR 25,000 for children. Whereas for domestic tourists it is IDR 15,000 for adults and IDR 10,000 for children. Based on the Decree of the Head of the Bangli Second Level 
Region Number 116 of 1993, the income obtained was distributed $40 \%$ for desa adat $60 \%$ for the Bangli Regency Government. The distribution of desa adat is $20 \%$ distributed to levies, $10 \%$ for maintenance of cleanliness and $10 \%$ for maintenance of order and security.

In its implementation, the management institution takes a policy that out of $40 \%$ of the funds obtained is allocated $20 \%$ for operations such as employee salaries, meetings, and maintenance costs such as cleanliness and landscaping and security and order; and $20 \%$ for desa adat. From the results of the distribution of tourism village management, the income of Penglipuran Customary Village in 2013 amounted to Rp103,683,581.00 increased in 2014 to Rp157,645,645.00. The funds are used for village development such as repairing sacred buildings, carrying out religious ceremonies, and subsidizing residential maintenance. The community in this case did not issue contributions for the benefit of the village. so indirectly rural communities are free from financial expenditure for external purposes. Thus, the funds owned by the community can be used to improve the fulfillment of family needs such as clothing, food, and family education.

Environmental wisdom also gives meaning to the opening of employment opportunities. To support the development of tourist villages in Penglipuran Village, small industries include (hand made) and food and beverages. The handicraft industry includes miniature paon and angkul-angkul made from bamboo and made a sokasi. Meanwhile, the food and beverage industry are in the form of sweet potato donuts, purple sweet potato chips, and sweet potato chips; and typical drinks like loloh cemcem and loloh temu. These foods and drinks are processed by the community with materials obtained in the village. To support the development of tourist villages, the community also opened food stalls and souvenir stalls in the yard, and made lodging (homestay) at the back of the yard (tebe). From the business of selling people's income, it reaches Rp. 300,000 - Rp1,000,000.00 per day. As for lodging in Penglipuran Village, there are several types with prices ranging from Rp. 200,000 to Rp. 500,000 per day. Home stay bookings are made through a management institution with a share of $15 \%$ for managing institutions, $5 \%$ for traditional villages, and $80 \%$ for home stay owners. Thus, the environmental wisdom in managing tourism villages has given economic meaning both directly and indirectly to the community in the form of increasing community welfare. This is in line with Government Regulation Number 2 of 2012 concerning Cultural Tourism which states tourism destinations are to increase economic growth, improve people's welfare, create business opportunities and create jobs.

The explanation above shows that the desa adat Penglipuran has the power and knowledge about environmental conservation. Knowledge about the environment in the form of rules and traditions that are used as guidelines and implemented by the community. On the contrary the people are very obedient to the existing rules. With local knowledge owned by desa adat, they have power in developing tourism villages. The involvement of desa adat directly with the highest position in the structure of desa adat management institutions can direct the development of Penglipuran village as a tourist village. This is in line with Michel Foucault's theory of power of knowledge that the implementation of power creates knowledge, whereas knowledge creates influences of power [11]. The technique of power is aimed at obedience which has concrete meaning. The meaning lies in the attitudes, beliefs, goals, truths, and reasons used by everyday people. The meaning shows that something has meaning and guides actions as an explanation and justification for these actions "after they occur" [10]. 


\section{Conclusion}

Based on the explanation above it can be concluded that the form of environmental wisdom in the management of Penglipuran tourism village includes wisdom in settlement management, forest management, and tourism village management. The meaning of environmental wisdom in the management of Penglipuran tourism village includes the meaning of nature preservation, socio-cultural meaning, and economic meaning.

\section{References}

[1] Ardikan, I. W.: Pusaka Budaya \& Pariwisata. Pustaka Larasan, Denpasar (2007)

[2] Sutaba, I. M.: Merajut Kearifan Lokal Membangun Karakter Bangsa. Balai Arkeologi, Denpasar (2012)

[3] Dalem, A. A. G. R.: Kearifan Lokal dalam pengelolaan Lingkungan. Universits Udayana bekerjasama dengan Pusat Penelitian Lingkungan Hidup Unud, Denpasar (2007)

[4] Moleong, L. J.: Metodologi Penelitian Kualitatif. UI Press, Jakarta (1991)

[5] Ratna, N. K.: Metodologi Penelitian Kajian Budaya dan ilmu Sosial Humaniora pada Umumnya. Pustaka Pelajar, Yogyakarta (2010)

[6] Nawawi, H.: Instrumen Penelitian Bidang Sosial. Gadjah Mada University Press, Yogyakarta (1992).

[7] Miles, Matthew., \& Huberman, A. M.: Analisis Data Kualitatif. UI Press, Jakarta (1992)

[8] Laksmi, A. A. R. S.: Cagar Budaya Bali Menggali Kearifan Lokal dan Model Pelestariannya. Udayana University Press, Denpasar (2011)

[9] Ginting, I. S.: Etika Lingkungan. Udayana University Press, Denpasar (2012)

[10] Barker, C.: Cultural Studies: Teori dan Praktek. PT. Bentang Budaya, Yogyakarta (2014)

[11] Sarup, M.: Panduan Pengantar untuk Memahami Postrukturalisme dan Posmodernisme. Jalasutra, Yogyakarta (2011)

[12] Awig-Awig Desa Pakraman Penglipuran (2015)

[13] Undang-Undang RI Nomor 10 tahun 2009 tentang Kepariwisataan. Sinar Grafika, Jakarta (2009)

[14] Undang-Undang RI Nomor 32 Tahun 2009 tentang Perlindungan dan Pengelolaan Lingkungan Hidup. Kementerian Negara dan Lingkungan Hidup, Jakarta (2009)

[15] Peraturan Daerah Provinsi Bali Nomor 02 Tahun 2012 tentang Kepariwisataan Budaya Bali (2012)

[16] Profil Desa Wisata Penglipuran

[17] http://biohabbites.blogspot.com/ 